\title{
Okul Yöneticilerinin Psikolojik Sözleşme Algısı Ölçeğinin Geliştirilmesi*
}

\section{Development of School Administrators' Psychological Contract Perception Scale}

\begin{abstract}
Şenay Sezgin NARTGÜN **, Sibel DEMIRER***
Öz: Psikolojik sözleşme çalışanlar ve örgütler arasında yazılı olmayan beklentileri ifade etmektedir. Bu araştırmada, okul yöneticilerinin psikolojik sözleşme algılarını incelemeye yönelik "psikolojik sözleşme algısı ölçeği" geliştirilmesi amaçlanmaktadır. Ölçeğin geçerliği için açımlayıcı faktör analizi (AFA) ve doğrulayıcı faktör analizinden (DFA) yararlanılmıştır. Ölçeğin açımlayıcı faktör analizi, doğrulayıcı faktör analizi ve nihai uygulaması için veriler üç farklı çalışma grubundan toplanmıştır. Faktör analizi sonucunda 20 maddeden; işlemsel, ilişsisel ve dengeli sözleşme boyutlarından oluşan Okul Yöneticilerinin Psikolojik Sözleşme Algısı Ölçeği geliştirilmiştir. Geliştirilen ölçek Bolu ilinde görev yapan 249 ilkokul, ortaokul ve lise okul yöneticisine uygulanmıştır. Ölçeğin güvenirliği için Cronbach's Alpha değerleri hesaplanmış ve işlemsel sözleşme boyutunda, 70 ; ilişkisel sözleşme boyutunda, 85 ; dengeli sözleşme boyutunda, 95 ve toplam psikolojik sözleşme ölçeğinde ,88 olarak bulunmuştur. Bolu ilinde görev yapan 249 okul yöneticisinden elde edilen verilerle betimsel analiz yapılmış ve okul yöneticilerinin psikolojik sözleşmeye ilişkin ilişkisel sözleşme, dengeli sözleşme ve toplam psikolojik sözleşme algılarının "katılıyorum" düzeyinde olduğu ve işlemsel sözleşme algılarının ise "kararsızım" düzeyinde olduğu tespit edilmiştir.
\end{abstract}

Anahtar Kelimeler: Psikolojik sözleşme, okul yöneticileri, ölçek geliştirme

\begin{abstract}
Psychological contract emphasizes to unwritten expectations among employees and organizations. In this study, it is aimed to develop a psychological contract perception scale to examine school administrators' perceptions of psychological contracts. Explanatory factor analysis (EFA) and confirmatory factor analysis (CFA) were used for the validity of the scale. The data were collected from three different study groups for exploratory factor analysis, confirmatory factor analysis and final application of the scale. As a result of factor analysis, The School Administrators' Psychological Contract Perception Scale which consists of 20 items and three dimensions as transactional, relational and balanced contract, was developed. The developed scale was applied to 249 primary, secondary and high school administrators working in Bolu. For the reliability of the scale, Cronbach's Alpha values were calculated and the Cronbach Alpha values of this study were ,70 for transactional contract; , 85 for relational contract; ,95 for balanced contract and ,88 for total psychological contract scale. A descriptive analysis was made with the data obtained from 249 school administrators working in Bolu, and it was determined that school administrators' perceptions of relational contract, balanced contract and total psychological contract were at the level of agree, and the perceptions of transactional contract were at the level of 'neither agree nor disagree'.
\end{abstract}

Keywords: Psychological contract, school administrators, scale development

\section{Giriş}

Günümüzde örgütlerin var olmasında ve işleyişinde çalışan faktörünün önemi oldukça fazladır. Örgüt tarafından çalışanın örgütle kuracağı bağın güçlenmesi ve örgüte karşı yükümlülüklerinden fazlasını yapma çabası göstermesi istenmektedir. Örgütler tarafından çalışanları bünyesine katmak ve daha iyi imkânlar sunarak örgütten ayrılmasını engelleyebilmek için çalışanların

\footnotetext{
* Okul Yöneticilerinin Sosyal Takas, Özümseme Kapasitesi Düzeyleri ve Psikolojik Sözleşme Algıları Arasındaki İlişki başlıklı doktora tezinden üretilmiştir.

** Prof. Dr., Bolu Abant İzzet Baysal Üniversitesi, Eğitim Fakültesi, Bolu, ORCID: 0000-0002-5405-1655, e-posta: szbn@yahoo.com

*** Dr., Milli Eğitim Bakanlığı, Müdür Yardımcısı, Bolu, ORCID: 0000-0002-3904-2748, e-posta: 223444.sibel@gmail.com
} 
psikolojik özelliklerinin değerlendirilmesi önem kazanmaktadır. Çalışanların psikolojik ve duygusal özellikleri örgütün karmaşık yapısını önemli oranda arttırmaktadır. Çalışanların psikolojik beklentilerinin boyutu insan psikolojisinden bağımsız değerlendirilememektedir. En başta bireylerin hayattaki gereksinimlerinin karşılanmasına yönelik en önemli unsur kabul edilen ücret, sosyal haklar iş sözleşmelerinde ön planda tutulmaktadır. İşe alımlarda ücret ve prim sistemi, yıllık izin gibi koşullar iş sözleşmesinde belirtilirken bireyin karşılanmasını istediği yazılı olmayan beklentileri de bulunmaktadır. Örneğin bu beklentiler arasında sayılabilecek maaşına artış istemesi, ekstra çalışmalarının ödüllendirilmesi ve çalışanlar arasında adaletli ücretlendirme beklentisi bireyin çalışma hayatındaki mutluluğunu etkilemektedir. Diğer taraftan kişisel gelişimi için sosyal çevre edinme ihtiyacı duyan çalışanın örgütün kurslar, seminer ve sosyal aktiviteler organize etmesi yönünde beklentisi olabilir. Bu durumlar örgüt ile birey arasında yasal sözleşmede belirtilmezken bireyin zihninde örgüte bağl1lı̆̆ını test etmektedir. Çalışanlar sürekli değişen koşullarda, beklentilerine karşılık bulacakları örgütlerde bulunma isteği duymaktadırlar. Örgütler ise deneyimli ve uzman çalışanların örgütte kalmasını, bağl1lık göstermesini, örgütsel amaçları gerçekleştirmek için fazladan çaba sarf etmelerini ve yüksek performans düzeyi göstermelerini istemektedirler. Birey ve örgüt arasındaki yasal sözleşme haricindeki bu tür karşılıklı beklentiler psikolojik sözleşme olarak ele alınmaktadır.

\section{Psikolojik sözleşme}

Sözleşme kavramı bir anlaşmayı veya bir anlaşmanın dışa dönük görünümünü ifade etmektedir (Cullinane ve Dundon, 2006). Çalışanın örgüte dahil olmasıyla örgüt ile çalışan arasında çoğunlukla çalışanın yapacağ 1 iş, alacağ 1 ücret ile işverenin yapacaklarını ve karşılığında elde edeceği unsurları kapsayan yazılı sözleşmeler yapılmaktadır ve yapılan bu sözleşmeler yasal sözleşme olarak isimlendirilmektedir. Çift yönlü olan bu sözleşmeler yazılı nitelikte değil ise psikolojik sözleşme adını almaktadır (Miles, 2012). Diğer bir ifadeyle yasal sözleşme iki taraf arasında resmi, yazılı veya sözlü bir sözleşmedir. Bu sebeple her iki tarafın şart ve koşulları okuduklarını ve kabul ettiklerini göstermektedir. Yasal sözleşmelerin tarafların rızası olmadan değişmesi oldukça zor olmaktadır (Cullinane ve Dundon, 2006). Yasal ve ekonomik sözleşme ile birlikte taraflar arasında psikolojik sözleşme de meydana gelmektedir (Kaldırımcı, 1987).

Psikolojik sözleşmenin ilk tanımları Argyris (1960) ile Levinson, Price, Munden, Mandl ve Solley (1962) tarafından yapılmıştır. Argyris (1960) psikolojik iş sözleşmesi terimini, örgüt ve bireyin iş ilişkisine verdiği değeri ifade etmek için kullanmıştır. Levinson ve diğerleri (1962) psikolojik sözleşmeyi ilişkinin taraflarının karşılıklı ilişkilerinin belirlediği ve birbirleriyle olan ilişskilerini yönetmelerine temel olacak bir dizi ortak beklentiler olarak tanımlamıştır. Başka bir ifadeyle bireyin psikolojik sözleşmeye olan inancı bir sosyal normun kabulünden daha fazlası olup gelecekte bir vaadin gerçekleşeceğine, kabul edilen katkısına ve gelecek için yükümlülüklerin var olduğuna dair inancıdır (Rousseau, 1989). Kotter (1973) psikolojik sözleşmeyi çalışan ile örgüt arasında iş ilişkisi çerçevesinde birbirlerinden beklentileri ve taahhütlerine dayanan psikolojik yönü bulunan örtülü anlaşma olarak tanımlamıştır.

Örgütsel amaçların başarılmasını sağlamaya, bireyleri ve örgütleri bir araya getirmeye ve davranışlarını düzenlemeye hizmet eden sözleşmeler, örgütlerin gerekli bir özelliği olma niteliği taşımaktadır (Robinson, Krattz ve Rousseau, 1994). Bireyler ve örgütler arasındaki sözleşmeler, çalışanların ilişkilerinde çalışanın sözleşme kavramını kabulü için gerekli katkı ve bağlılığa dikkat çeken bireysel hareketleri veya işe alım, iş değişimi, örgütsel değişim ve gelişîm, grup oluşturma, yeniden yapılandırma gibi kritik birleşme noktalarını düzenlemektedir (Rousseau ve McLean Parks, 1993). Psikolojik sözleşmenin taraflar arasındaki kabulü ise karşıllklılık ilkesine dayanmaktadır. Bireyin psikolojik sözleşmesinin oluşması, karş1lıklılığın meydana geleceğine ve yükümlülüklerin yerine getirileceğine olan inancına bağlı olmaktadır. Bu inanç tek taraflı, ilişkide olan diğer tarafları etkilemeyen bireyin belirlediği niteliktedir (Rousseau, 1989). Diğer bir ifadeyle psikolojik sözleşme bir tarafın sözleşme yükümlülüklerini yerine getirmesi diğerinin yükümlülüklerini yerine getirme şartına bağlı olduğuna inanması ve bir taahhüdün açıkça veya örtük olarak yapılmasıyla ortaya çıkmaktadır. Bunun sonucunda bireyin, kendisi ile işvereni arasındaki yükümlülükleri algılamasında karşılıklılık ilkesinin varlığına inanmasıyla psikolojik 
sözleşme devam etmektedir (Coyle-Shapiro ve Parzefall, 2008; Rousseau, 1989). Günümüzde iş ilişkisini tanımlamak ve anlamak için psikolojik sözleşmeler daha önemli bir rol oynamaktadır.

Psikolojik sözleşmenin kurulmasında kritik öneme sahip unsurlar olan örtük veya açık vaatlerin sunulacağı ve bunun karşıllı̆ında bir bedelin varlığına olan inançlarına bağlı olarak, bireyler örgütlerine yaptıkları katkılar karşılığında örgütün onlara belirli ödüller vermeyi kabul ettiğini algıladıklarında psikolojik sözleşmeler sürdürülmektedir (Turnley ve Feldman, 2000). Psikolojik sözleşmeler özelliği gereği sürekli devam eden nitelikte olup tarafların sözleşmeye yönelik algılarındaki değişikliklerle devam etmeye eğilimlidir (Miles, 2012).

\section{Psikolojik sözleşmenin boyutları}

İşlemsel 'transactional' ve ilişkisel 'relational' kavramı psikolojik sözleşmesinin temel bileşenleridir (Aselage ve Eisenberger, 2003; De Vos, Buyens ve Schalk, 2003; Macneil, 1985; Millward ve Hopkins, 1998; Rousseau, 1995, 2000; Rousseau ve McLean Parks, 1993). Örgütlerdeki değişim ve geçiş sürecinde oluşan psikolojik sözleşmeleri de dikkate alan boyutlandırmada psikolojik sözleşmeler işlemsel, ilişkisel, dengeli ve geçişli olmak üzere dört türe ayrılmaktadır (Anderson ve Schalk, 1998; Patrick, 2008; Robinson ve diğerleri, 1994). Bu dört boyutun özellikleri aşağıdaki gibi açıklanabilir (Rousseau, 2000):

a) Işslemsel sözleşmeler: Kısa vadeli veya sınırlı süreli, öncelikli olarak ekonomik değişime odaklanan ve örgütte dar görevlerle sınırlı çalışan katılımını öngören istihdam düzenlemeleridir (Rousseau, 2000). İşlemsel sözleşme, çalışan ile örgüt arasında parasal değişime bağlı geçici ilişkiyi temsil etmektedir (Conway ve Coyle-Shapiro, 2012). İşlemsel sözleşmelerin özellikleri şu şekilde sıralanabilir: (1) Sınırlılık: Çalışanın, yalnızca kendisine ödemesi yapılan, sabit ve sınırlı görevler yürütmesi zorunludur. İşveren, çalışanlara örgüte sınırlı katılımı, az eğitim almayı veya hiç eğitim almamayı taahhüt etmiştir. (2) Kısa vadeli olma: Çalışanın örgütte kalma zorunluluğu yoktur. İşveren sadece belirli veya sınırlı bir süre için istihdam sunar, gelecek için taahhüt vermesi zorunlu değildir (Rousseau, 2000).

b) Illişkisel sözleşmeler: Karş11ıklı güven ve sadakat temelli uzun vadeli veya açık uçlu istihdam düzenlemeleridir. İlişkisel sözleşmeye sahip çalışanlardan sadakati ve örgüt tarafından iş güvencesi verilmesi gibi uzun vadeli bir ilişkiyi yansıtacak olan işveren ve çalışan odaklı yükümlülükleri göstermesi beklenmektedir (Rousseau, 1990). İlişkisel sözleşmeler yetkin yönetim, giriş firsatı ve aidiyet duygusu karşılığında çalışanın örgüte sunduğu bağlılık ve sadakat ile yönetime güven duyma gibi faktörleri kapsamaktadır (Maguire, 2002). İlişkisel sözleşmelerin özellikleri şu şekilde sıralanabilir (Rousseau, 2000): (1) İstikrar: Çalışan, örgüt ile birlikte kalmak ve işini korumak için gerekenleri yapmakla yükümlüdür. İşveren sabit ücret ve uzun vadeli istihdam sunmayı taahhüt etmiştir. (2) Sadakat: Çalışan örgütü destekleme, örgütün ihtiyaç ve ilgilerine bağl1lık duyma ve bağl1lığı gösterme yükümlülüğü altındadır.

c) Dengeli sözleşmeler: Kariyer avantajları geliştirmek için çalışanlara örgüt tarafından sunulan ekonomik başarı ile koşullandırılmış fırsatlara dayanan dinamik ve açık uçlu istihdam düzenlemeleridir. Hem örgüt hem de çalışan birbirlerinin öğrenme ve gelişimlerine büyük katkıda bulunmaktadır. Dengeli sözleşmelerin özellikleri şu şekilde sıralanabilir (Rousseau, 2000): (1) Dış istihdam edilebilirlik: Çalışanlar dış işgücü piyasasında kariyer gelişimine yönelik kabul edilebilir beceriler geliştirmekle yükümlüdür; işveren ise bunun için yardımcı olduğunu göstermektedir. (2) İç ilerleme: İç işgücü piyasasında kariyer gelişimine yönelik olarak çalişan mevcut işveren tarafından değer verilen yetenekleri geliştirmekle yükümlüdür. İşveren çalışana örgüt bünyesinde kariyer geliştirme firsatları yaratmayı taahhüt etmiştir. (3) Dinamik performans: Çalışan, örgütün rekabet etmesine yardımcı olmak için gelecekte değişebilecek yeni ve daha zorlu hedefleri yerine getirmekle yükümlüdür. İşveren, sürekli öğrenmeyi teşvik etmeyi ve çalışanların artan performans gereksinimlerini başarıyla yürütmelerine yardımcı olmayı taahhüt etmiştir. 
d) Geçişli sözleşmeler: Psikolojik sözleşme formu değildir, önceden oluşturulmuş bir istihdam düzenlemesi ile çelişen geçişleri ve örgütsel değişimin sonuçlarını yansıtan bilişsel bir ifadedir. İşveren ve çalışanın gelecekteki taahhütleri konusunda belirsizlik görülmektedir.

Psikolojik sözleşme kavramı son y1llarda istihdam ilişkisinin yönlerini incelemek için bir çerçeve olarak giderek daha fazla kullanılmaya başlanmıştır. Bunun önemli bir nedeni, örgütte farklı düzeylerde uygulanabilecek bir analitik çerçeve sağlamasıdır (Guest ve Conway, 2002). Psikolojik sözleşmenin maddelerini verilen vaatler, çalışana ilişkin yönetsel uygulamalar, diğer çalışanlara verilen ödüller, özgeçmişle ilgili bilgiler gibi farklı niteliklerle açıklanabilen koşullar oluşturmaktadır (Bilgin, 2007). Bu durum yeni gelenleri gelecekteki olayları tahmin etmeleri ve beklentilerini değiştirmek için deneyimlerini aktif bir şekilde yorumlamaları ve böylece psikolojik sözleşme șemalarını eksiksiz hale getirmeleri yönünde motive etmektedir. Bu deneyimler, her iki tarafın da iş ilişkisine, yani işverenin sağladığı teşviklere ve çalışanın katkılarına ilişkin sözleşme davranışlarına bağlıdır (De Vos ve diğerleri, 2003).

Psikolojik sözleşmenin oluşumunda bir tarafın eylemlerinin diğerinin eylemlerine bağlı olduğu bir ilişkinin var olduğuna ve desteğin yerine getirileceğine dair inançtan doğan güvenin algılanması önem taşımaktadır (Rousseau, 1989:128). İş ilişkilerinin değişen özerk ve farklı doğası göz önüne alındığında, psikolojik sözleşme kavramı örgüt ile ilgili örtük ve açık beklentileri olan bireylerin ihtiyaçlarını yansıtan bir çerçeve oluşturmaktadır (Cullinane ve Dundon, 2006). Hem örgütün hem de bireyin iş ilişkilerini nasıl anladıklarına dair öznelliklerine rağmen her iki tarafa da fayda sağlayacak bir sözleşme oluşurken sözleşmenin yapısı büyük ölçüde her bir tarafın karşılıklılık algısına ve güvencesine dayanmaktadır (Dabos ve Rousseau, 2004; Rousseau, 1995; Rousseau ve McLean Parks, 1993). Aynı zamanda psikolojik sözleșme algılanan vaat ve yükümlülüklerin iki yönlü değişimine bağlıdır ve tarafların bu ilişkide karşılıklı taahhütleri ve yükümlülükleri iş ilişkisine ilişkin algılarını etkilemektedir (Guest ve Conway, 2002; Herriot ve Pemberton, 1997).

\section{Eğitim örgütlerinde psikolojik sözleşme}

Yasal sözleşmelerle birlikte örgüt ve birey arasında psikolojik sözleşmenin varlığı gündeme gelmektedir. Yasal sözleşmeler öğretmenlerle kurum arasında olmakla birlikte yükümlülük ve beklentilere bağlı olarak okul yöneticisi ile öğretmen arasında; üst yönetim ve okul yöneticisi arasında psikolojik sözleşme oluşmaktadır. Farklı okullarda yaşadığı deneyimler öğretmen ve okul yöneticilerinin psikolojik sözleşme algısını olumlu veya olumsuz yönde etkilemektedir. Bu durum bireysel farklılıkların olduğu kadar örgütsel farklılıkların da psikolojik sözleşmede etkili olmasından kaynaklanabilmektedir. Okullar arasında yönetim anlayışının ve bulunduğu çevrenin farklı olması psikolojik sözleşmeyi etkileyen faktörler arasında sayılabilir. Buradan hareketle birçok okulda çalışan okul yöneticileri ve öğretmenler için uzun y1llar boyunca edinilen deneyimlerin psikolojik sözleşme algısında etkisi olduğu ifade edilebilir.

Öğretmenler ve okul yöneticileri eğitim süresi ve kıdem yıllarına göre maaş ve terfi imkânlarından faydalandırılmaktadırlar. Göreve başlama sürecinden önce adayların çalışma şartları, maaş ve ek ders ücretleri hakkında bilgisi bulunduğu ve dolayısıyla başvuru yapan bireylerin kendilerine sunulan yasal düzenlemeleri kabul ettiği söylenebilir. Bu durumda atama kararnamesi ile görevine başlayan öğretmenle resmi kurum arasında yasal sözleşme oluşmaktadır. Yönetici seçim sürecinde ise adayların belirli süre öğretmen olarak çalışma şartı bulunmaktadır. Yönetici olabilmesi için mevzuata hâkim olması ve belirli bir görev süresini tamamlamış olması gereken öğretmen, aynı zamanda yöneticilerin görevleri ve çalışma şartları ile ilgili bilgiye sahip olmaktadır. Buna göre yönetici olmaya karar vermeden önce araştırma ve yöneticilik görevinin kendisine uygun olup olmadığı yönünde değerlendirme yapabilme imkânı bulunmaktadır. Öğretmenlerin ve yöneticilerin maaşının, yıllık eğitim-öğretim ödeneğinin ve nöbet, sınav görevleri, girdiği ders saatine bağlı olarak ek ders, kurs gibi yaptığı ekstra çalışmaların ek ücretlerinin ödenmesi gerekliliği yasal düzenlemelerle belirtilmiştir. Yasal düzenlemelerde belirtilen öğretmenlerin ve okul yöneticilerinin haftalık girmesi gereken ders saatleri, yapması gereken görevler ve uyması gereken kurallar örgütün beklentilerini oluşturmaktadır. 
Okul yöneticisinin psikolojik sözleşme algısını etkileyen önemli unsurlardan birini de kurumları ve üst yönetimle arasındaki ilişkiler oluşturmaktadır. Bu bağlamda okul yöneticileri için üç psikolojik sözleşme türünden söz etmek mümkün olmaktadır. Birinci olan işlemsel psikolojik sözleşmede yönetici tarafından algılanan psikolojik sözleşme sınırlı ve kısa sürelidir. $\mathrm{Bu}$ psikolojik sözleşme türüne göre yönetici kendi belirlediği hedefleri kısa sürelerle sınırlandırabilmektedir. Başka bir ifadeyle görev süresi kısa olduğunda ulaşmak için belirleyeceği hedefler de kısa vadeli olabilmektedir. Kısaca işlemsel psikolojik sözleşme algısına göre okul yöneticisinin yönetim anlayışı işinin gereklerini yerine getirmekle sınırlanabilmektedir. Ayrıca işlemsel psikolojik sözleşmede okul yöneticisine okuldaki görevine devam edeceğine dair taahhüt verilmemektedir. İkinci olarak ilişkisel sözleşmede okul yöneticisi ile çalıştıkları kurum arasında uzun süreli, duygusal bağlılığa dayalı bir ilişkinin mevcut olduğu söylenebilir. Bu psikolojik sözleşme türünde okul yöneticisi ile üst yönetim arasında karşılıklı güvene dayalı ve sadakat temelli bir ilişki bulunmaktadır. Yöneticilerin yöneticilik görevlerinin devam edeceğine ilişkin iş güvencelerinin olduğuna dair inançlarının olması, belirlenen uzun vadeli hedefler için belli bir süreye bağlı olmadan fazladan çalışma davranışı gösterme veya uzun mesai saatlerini kabul etme yöneticiler için genellikle ilişkisel psikolojik sözleşme algıları ile ilişkili görülen davranışlar olarak sıralanabilmektedir. Üçüncü olarak dengeli sözleşmede okul yöneticisinin kariyer gelişimine, öğrenme ve gelişim imkânlarına ilişkin inancı bulunmaktadır. Okul yöneticilerinin ön planda olan psikolojik sözleşme türünün belirlenmesinde kişisel özelliklerinin ve deneyimlerinin yanı sıra üst yönetimin tutumu ve desteği de etkili olabilmektedir. Bu bağlamda psikolojik sözleşme algıs1 okul yöneticisinin eğitim için üst düzeyde performans göstermesini sağlamaktadır. Psikolojik sözleşme türleri, eğitim açısından kritik öneme sahip olan okul yöneticisinin çalışma davranışlarını ve bağlılık ile sadakat algılarını şekillendirmektedir. Sonuç olarak okul yöneticilerinin psikolojik sözleşme algılarını arttırmanın önemi ortaya çıkmaktadır.

\section{Araştırmanın amacı}

$\mathrm{Bu}$ araştırmada okul yöneticilerinin psikolojik sözleşmeye ilişkin görüşlerini belirlemeye yönelik geliştirilen Psikolojik Sözleşme Algısı Ölçeği’nin geçerlik-güvenirlik çalışmaları yapılması amaçlanmıştır. Böylece araştırmada eğitim örgütlerinde önemli beklenti ve yükümlülükler taşıyan okul yöneticilerinin psikolojik sözleşme algı düzeylerinin belirlenmesi için bulguların elde edilmesi de istenmektedir.

\section{Yöntem}

\section{Araştırmanın çalışma grupları}

Çalışma Bolu Valiliği’nden Araştırma İzni alınarak ve Bolu Abant İzzet Baysal Üniversitesi Sosyal Bilimlerde İnsan Araştırmaları Etik Kurulu 26.03.2019 tarih ve 2019/3 (protokol no. 2019/136) sayılı izni ile yapılmıştır. Araştırma ve yayın etiğine uyulmuştur. Araştırmanın çalışma gruplarını 2018-2019 eğitim ve öğretim yılında Türkiye'nin farklı illerinde ilkokul, ortaokul ve liselerde görev yapan okul yöneticileri oluşturmaktadır. Ölçeğin açımlayıcı faktör analizi (AFA) için veriler araştırmanın birinci çalışma grubunu oluşturan 2018-2019 eğitim-öğretim yılında Sakarya ve Ankara illerinde ilkokul, ortaokul ve liselerde görev yapan 256 okul yöneticisinden toplanmıştır. Doğrulayıcı faktör analizi (DFA) için veriler araştırmanın ikinci çalışma grubunu oluşturan İzmir, Bursa ve Düzce'de ilkokul, ortaokul ve liselerde görev yapan 252 okul yöneticisinden sağlanmıştır. Son şeklini alan ölçeğin betimsel istatistikleri üçüncü çalışma grubu ile yürütülmüştür. Betimsel analiz 2018-2019 eğitim-öğretim yılında Nisan-Mayıs aylarında Bolu ilinde ilkokul, ortaokul ve liselerde görev yapan 249 okul yöneticisinden elde edilen verilerle yapılmıştır. Geri dönüş oranı araştırma evreninin \%73'ünü oluşturmaktadır. Araştırmaya katılan okul yöneticilerinin 63'ü $(\% 25,3)$ kadın, 186'sı $(\% 74,7)$ erkek; 95'i $(\% 38,2)$ okul müdürü ve 154 'ü $(\% 61,8)$ müdür yardımcıs1; 56's1 (\%22,5) “ilkokul”da, 75'i $(\% 30,1)$ “ortaokul”da ve 118 'i $(\% 47,4)$ "lise"de görevli; 46’s1 (\%18,5) "35 yaş ve altı”, 47' si (\%18,9) “36-40 yaş arası”, 67'si $(\% 26,9)$ “41-45 yaş arası”, 44'ü (\%17,7) “46-50 yaş arası”, 45'i $(\% 18,0)$ "51 yaş ve üzeri” okul yöneticilerinden oluşmaktadır. 


\section{Veri toplama araçları}

Okul yöneticilerinin psikolojik sözleşme algılarını ölçmek için yapılan alanyazın taraması sonucu Millward ve Hopkins (1998) tarafından geliştirilen Türkçe uyarlaması Mimaroğlu (2008) tarafından yapılan 10 maddesi psikolojik sözleşmenin işlemsel alt boyutunu ve 7 maddesi psikolojik sözleşmenin ilişkisel alt boyutunu ölçen iki boyutlu toplam 17 maddelik psikolojik sözleşme ölçeğine ulaşılmıştır. Millward ve Hopkins (1998) tarafından geliştirilen Türkçe uyarlaması Mimaroğlu (2008) yapılan psikolojik sözleşme ölçeğinden ve Rousseau (2000) tarafından geliştirilen Demirkasımoğlu (2012) tarafından Türkçe uyarlaması yapılan "Psikolojik Sözleşme Envanterinin (PSE)" "Okulun Öğretmenlere Karşı Yükümlülükleri” boyutundaki özellikle dengeli ve ilişkisel sözleşme ile ilgili maddelerinden yararlanılması ve alanyazın taraması yapılarak maddeler eklenmesi sonucu okul yöneticilerinin psikolojik sözleşme algılarını ölçmek için ölçek geliştirilmesi gereği duyulmuştur. Bu çalışmada okul yöneticilerinin psikolojik sözleşme algısı işlemsel, ilişkisel ve dengeli sözleşme şeklinde üç boyutlu olarak incelenmiştir. Puanlama sinırları "Kesinlikle katılmıyorum" (1/ 1,00-1,79), "Katılmıyorum" (2/ 1,80-2,59), "Kararsızım" (3/ 2,60-3,39), "Katıliyorum" (4/ 3,40-4,19), "Kesinlikle kat1liyorum" (5/ 4,20$5,00)$ " şeklinde olan ölçek 5'li Likert tipindedir.

\section{Verilerin analizi}

Ölçeğin geçerlik çalışması için açımlayıcı ve doğrulayıcı faktör analizleri elde edilen ölçme aracına sırasıyla uygulanmıştır. Açımlayıcı faktör analizi ve betimsel analiz için SPSS for Windows 17.0 programı ve doğrulayıcı faktör analizi (DFA) için ise Lisrel 8.71 programı kullanılmıştır. Bolu ilinde görev yapan 249 ilkokul, ortaokul ve lise yöneticisinden elde edilen verilerle SPSS programında kişisel bilgiler için frekans (f) ve yüzde (\%) değerleri ve ve okul yöneticilerinin psikolojik sözleşme algı düzeylerinin belirlenmesi için ölçekten alınan puanların aritmetik ortalama ve standart sapma değerleri hesaplanmıştır. Araştırmada anlamlılık düzeyi olarak ,05 alınmıştır. Ölçeğin güvenirliği için Cronbach's alpha katsayıları hesaplanmıştır.

\section{Psikolojik Sözleşme Algısı Ölçeği'nin boyutlarının belirlenmesi}

Alanyazın taraması sonucu psikolojik sözleşmenin işlemsel ve ilişkisel sözleşme (Aselage ve Eisenberger, 2003; De Vos ve diğerleri, 2003; Macneil, 1985; Millward ve Hopkins, 1998; Rousseau, 1995, 2000; Rousseau ve McLean Parks, 1993) şeklinde iki boyut olarak ele alındığ görülmektedir. Ayrıca bazı çalışmalarda çalışanlarla ilgili düzenlemeler işlemsel, ilişkisel ya da hibrit (dengeli) formda ele alınmaktadır (Rousseau, 1995, 2000; Rousseau ve Wade-Benzoni, 1994). Okul yöneticilerinin psikolojik sözleşme algısını belirlemek için gelişim ve öğrenmeye önem veren işlemsel ve ilişkisel sözleşmenin birleşimi olarak ifade edilen dengeli sözleşme formu da dikkate alınmıştır. Sonuç olarak bu araştırmada okul yöneticilerinin görüşlerine göre psikolojik sözleşmenin işlemsel, ilişkisel ve bu iki boyutun hibriti olan dengeli sözleşme şeklinde üç boyutlu değerlendirilmesine karar verilmiştir.

\section{Psikolojik Sözleşme Algısı Ölçeği’nin geçerlik ve güvenirlik çalışmaları}

Geçerlik çalışmasında faktör analizi, analizin amacı dikkate alındığında açımlayıcı (keşfedici, exploratory) ve doğrulayıcı (confirmatory) olmak üzere iki temel yönteme ayrılmaktadır (Büyüköztürk, 2002). Açımlayıcı faktör analizi (AFA) ölçek gelişiminde açıklayıcı bir aşama olarak kullanılırken doğrulayıcı faktör analizi (DFA) AFA'da tanımlanan yapının yeni bir örnekte çalışıp çalışmadığını kontrol etmede ikinci adım olarak kullanılabilmektedir (Erkorkmaz, Etikan, Damar, Özdamar ve Sanisoğlu, 2013). AFA faktör sayısını, faktörlerin ilişkili olup olmadığını ve her faktör için hangi gözlenen değişkenin en iyi ölçüt olduğunu ortaya koymaktadır (Schumacker ve Lomax, 2016; Tezcan, 2008).

\section{Bulgular}

İlgili literatürün taranması ve madde havuzunun oluşturulması

Yurt içi ve yurt dışında yapılan çalışmalar incelenerek çalışanların psikolojik sözleşme algılarını ölçmek için Millward ve Hopkins (1998) tarafından geliştirilen Türkçe uyarlaması Mimaroğlu 
(2008) yapılan psikolojik sözleşme ölçeğine ve Rousseau (2000) tarafından geliştirilen Demirkasımoğlu (2012) tarafından Türkçe uyarlaması yapılan "Psikolojik Sözleşme Envanterine (PSE)" ulaşılmıştır. Okul yöneticilerinin psikolojik sözleşme algılarını belirlemeye yönelik ölçek geliştirmek için ölçeklerin ilgili maddelerinden yararlanılması ve alanyazın taraması sonucu elde edilen yeni maddelerin eklenmesi suretiyle aday maddeler belirlenmiştir.

22 maddeden oluşan taslak ölçek için Eğitim Yönetimi ile Ölçme ve Değerlendirme uzmanlarının her bir madde için "madde gereklidir", "madde kullanılabilir ancak gereksizdir" ve "madde gereksizdir" seçeneklerinden birini seçmelerini sağlayacak şekilde form düzenlenmiştir. Lawshe (1975) tarafından verilen KGO hesaplama yöntemi ile mevcut araştırma için gerekli değerin ,62 ve üzerinde olması gerekmektedir. Tablo 1'de okul yöneticilerine yönelik psikolojik sözleşme algısı ölçeği aday maddelerine ilişkin uzmanlardan alınan dönütlerle hesaplanan kapsam geçerlik oranları sunulmuştur.

Tablo 1.

Psikolojik Sözleşme Algısı Ölçeği Aday Maddeleri Kapsam Geçerlilik Oranları

\section{PSIKKOLOJIKK SÖZLEŞME ALGISI ÖLÇEĞİ}
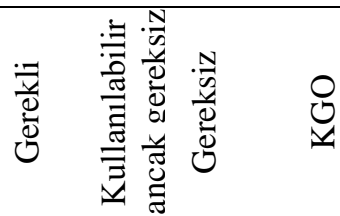

\begin{tabular}{|c|c|c|c|c|c|}
\hline 1 & $\begin{array}{l}\text { Yasal düzenlemeler bana gelecekte bu okulda çalışacağıma } \\
\text { dair bir güvence vermemektedir. }\end{array}$ & 9 & & 1 & 1,00 \\
\hline 2 & Bu okulda belirli bir süre için görevlendirildim. & 7 & 2 & 1 & $0,40 *$ \\
\hline 3 & $\begin{array}{l}\text { Bu okuldaki görevim, açıkça tanımlanmış belli yetki ve } \\
\text { sorumluluklarla sınırlandırılmıştır. }\end{array}$ & 10 & & & 1,00 \\
\hline 4 & $\begin{array}{l}\text { Üst yönetim benim, rutin görevleri yerine getirmemi } \\
\text { beklemektedir. }\end{array}$ & 10 & & & 1,00 \\
\hline 5 & Sadece işimin gereklerini yerine getiririm. & 9 & 1 & & 0,80 \\
\hline 6 & $\begin{array}{l}\text { Net olarak belirlenmiş iş saatleri içinde çalışmayı tercih } \\
\text { ederim. }\end{array}$ & 10 & & & 1,00 \\
\hline 7 & $\begin{array}{l}\text { Fazla çalışma için maddi kazanç ve ek ödeme almayı } \\
\text { beklerim. }\end{array}$ & 10 & & & 1,00 \\
\hline 8 & $\begin{array}{l}\text { Sadece belirlediğim kısa dönemli hedeflere ulaşmak için } \\
\text { çalışırım. }\end{array}$ & 9 & 1 & & 0,80 \\
\hline 9 & $\begin{array}{l}\text { Çalıştığım kurumda her konuda fazlasıyla sorumluluk } \\
\text { üstlenirim. }\end{array}$ & 10 & & & 1,00 \\
\hline 10 & $\begin{array}{l}\text { Bu kurumda kendimi takımın önemli bir parçası gibi } \\
\text { hissederim. }\end{array}$ & 10 & & & 1,00 \\
\hline 11 & $\mathrm{Bu}$ okulda uzun süre çalışmak isterim. & 10 & & & 1,00 \\
\hline 12 & $\begin{array}{l}\text { Hedeflere ulaşmak için gösterdiğim çabanın karşılığını } \\
\text { almayı beklerim. }\end{array}$ & 10 & & & 1,00 \\
\hline 13 & Yönetici olarak görevime devam etmek isterim. & 9 & 1 & & 1,00 \\
\hline 14 & Üst yönetim karar alırken, kişisel görüşlerimi dikkate alır. & 10 & & & 1,00 \\
\hline 15 & Üst yönetim, yaşadığım sorunlara karşı duyarlı davranır. & 10 & & & 1,00 \\
\hline 16 & $\begin{array}{l}\text { Üst yönetim, bir çalışan olarak kişisel mutluluğumu } \\
\text { önemser. }\end{array}$ & 10 & & & 1,00 \\
\hline 17 & $\begin{array}{l}\text { Üst yönetim, bu okuldan uzun vadede memnuniyetimi } \\
\text { sağlamak için üzerine düşeni yapar. }\end{array}$ & 9 & & -1 & 0,80 \\
\hline 18 & $\begin{array}{l}\text { Üst yönetim mümkün olan en üst düzeyde performansı } \\
\text { gösterebilmem için beni destekler. }\end{array}$ & 10 & & & 1,00 \\
\hline 19 & $\begin{array}{l}\text { Üst yönetim, eğitimde giderek yükselen standartları yerine } \\
\text { getirebilmem için bana yardımcı olur. }\end{array}$ & 10 & & & 1,00 \\
\hline
\end{tabular}


20 Üst yönetim değişen şartlara uyum sağlayabilmem için gerekli olanakları sağlar.

21 Çalıştığım kurum, mesleki gelişimimi sağlayacak eğitim ve yetişme olanakları sunar.

22 Çalıştı̆̆ım kurum, görevde yükselmem için firsatlar sunar.

10

Uzman görüşüne sunulan 21 maddenin kapsam geçerlik oranlarını (KGO) karşıladığı görülmüştür. Buna karşın "M2. Bu okulda belirli bir süre için görevlendirildim.” maddesi gerekli KGO oranını karşılamadığından ölçekten çıkarılarak uzman görüşleri doğrultusunda "Maddi karşıllğı olmayan görevleri de isteyerek yaparım." maddesinin ölçeğe eklenmesine karar verilmiştir. Sonuç olarak okul yöneticilerinin psikolojik sözleşme algısı ölçeğinde 22 aday madde yer almıştır. Eklenen maddelerle birlikte orijinal maddelerin (Demirkasımoğlu, 2012; Mimaroğlu, 2008) ve orijinal maddelerin düzenlenmesi ile elde edilen aday maddeler Tablo 2'de sunulmuştur.

Tablo 2.

Okul Yöneticilerinin Psikolojik Sözleşme Algısı Ölçeği Aday Maddeleri

Orijinal maddelerin düzenlenmesi ile elde edilen yeni maddeler

1 Yasal düzenlemeler bana gelecekte bu okulda çalışacağıma dair bir güvence vermemektedir.

2 Bu okuldaki görevim, açıkça tanımlanmış belli yetki ve sorumluluklarla sınırlandırılmıştır.

3 Üst yönetim benim, rutin görevleri yerine getirmemi beklemektedir.

4 Sadece işimin gereklerini yerine getiririm.

5 Net olarak belirlenmiş iş saatleri içinde çalışmayı tercih ederim.

6 Fazla çalışma için maddi kazanç ve ek ödeme almayı beklerim.

7 Sadece belirlediğim kısa dönemli hedeflere ulaşmak için çalışırım.

8 Maddi karşılığı olmayan görevleri de isteyerek yaparım.

9 Çalıştığım kurumda her konuda fazlasıyla sorumluluk üstlenirim.

10 Bu kurumda kendimi takımın önemli bir parçası gibi hissederim.

11 Bu okulda uzun süre çalışmak isterim.

12 Hedeflere ulaşmak için gösterdiğim çabanın karşılığını almayı beklerim.

13 Yönetici olarak görevime devam etmek isterim.

14 Üst yönetim karar alırken, kişisel görüşlerimi dikkate alır.

15 Üst yönetim, yaşadığım sorunlara karşı duyarlı davranır.

16 Üst yönetim, bir çalışan olarak kişisel mutluluğumu önemser.

17 Üst yönetim, bu okuldan uzun vadede memnuniyetimi sağlamak için üzerine düşeni yapar.

\section{Orijinal Madde}

(Demirkasımoğlu, 2012)

S19. Kurumum bana, gelecekte bu okulda çalışacağıma dair bir güvence vermemektedir. $\mathrm{S} 23$. İşim, açıkça tanımlanmış belli yetki ve sorumluluklarla sınırlandırılmıştır.

S24. Okul müdürü benden, yalnızca sıradan ve rutin görevleri yerine getirmemi beklemektedir. S11.Sadece işimin gereklerini yerine getiriyorum (Mimaroğlu, 2008).

S2. Net olarak belirlenmiş iş saatleri içinde çalışmayı tercih ederim (Mimaroğlu, 2008).

S6. Fazla mesai için ek ücret almayı bekliyorum (Mimaroğlu, 2008).

S15.Sadece kısa dönemli iş hedeflerine ulaşmak için çalışıyorum (Mimaroğlu, 2008).

S8. Bu firmada kendimi takımın bir parçası gibi hissediyorum (Mimaroğlu, 2008).

S16.Bu firmada sonuna kadar çalışırım (Mimaroğlu, 2008).

S27. Okul müdürü karar alırken, benim çıkarlarımı da dikkate alır.

S26. Okul müdürü, kişisel sorunlarıma karşı duyarlı davranır.

S25. Okul müdürü, bir çalışan olarak kişisel mutluluğumu önemser.

S28. Okul müdürü, bu okuldan uzun vadede memnuniyetimi sağlamak için üzerine düşeni yapar. 
18 Üst yönetim mümkün olan en üst düzeyde performansı gösterebilmem için beni destekler.

19 Üst yönetim, eğitimde giderek yükselen standartları yerine getirebilmem için bana yardımci olur.

20 Üst yönetim değişen şartlara uyum sağlayabilmem için gerekli olanakları sağlar.

21 Çalıştı̆̆ım kurum, mesleki gelişimimi sağlayacak eğitim ve yetişme olanakları sunar.

22 Çalıştığım kurum, görevde yükselmem için firsatlar sunar.
S32. Okul müdürü, mümkün olan en üst düzeyde performansı gösterebilmem için beni destekler.

S33. Okul müdürü, eğitimde giderek yükselen standartları yerine getirebilmem için bana yardımci olur.

S34. Bu okulda, değişen performans gerekliliklerine uyum sağlayabilmem için gerekli olanaklar sağlanır.

S36. Çalıştığım kurum, mesleki gelişimimi sağlayacak eğitim ve yetişme olanakları sunar. S38. Çalıştı̆̆ım kurumda, yükselme olanakları sunulmaktadır.

Tablo 2'de yer alan 22 maddelik 5'li likert tipi ölçek için açımlayıcı faktör analizi (AFA) uygulaması yapılmıştır. Ölçek geliştirme çalışması yapılan okul yöneticilerine yönelik Psikolojik Sözleşme Algısı Ölçeği'nin açımlayıcı faktör analizi (AFA) 256, doğrulayıcı faktör analizi 252 ölçekten elde edilen veriler ile yapılmıştır. Faktör analizinin yapılabilmesi için genel kural olarak örneklem büyüklüğünün en az gözlenen değişken sayısının beş katı olması gerektiği ifade edilmektedir (Büyüköztürk, 2002).

22 maddelik taslak psikolojik sözleşme algısı ölçeğinin açımlayıcı faktör analizinin 256 katılımcıya uygulanması örneklem büyüklüğünün yeterli olduğunu göstermektedir. Verilerin faktör analizine uygun olup olmadığ 1 ve çok değişkenli normallik varsayımının testi için KaiserMeyer Olkin (KMO) ve Bartlett Kürsellik Testi uygulanmıştır. Veri setinin faktör analizine uygun olması için KMO'nun 0,60'dan yüksek olmas1 gerekmektedir (Büyüköztürk, 2018). Okul yöneticilerinin psikolojik sözleşme algısı ölçeğinin Kaiser-Meyer-Olkin (KMO) ve Bartlett Küresellik Testi değerleri Tablo 3’te sunulmuştur.

Tablo 3.

Psikolojik Sözleşme Algısı Ölçeğinin Kaiser-Meyer-Olkin (KMO) ve Bartlett Küresellik Testi Değerleri

\begin{tabular}{lll}
\hline Kaiser-Meyer-Olkin (KMO) & &, 823 \\
\hline & $\chi 2$ & 3261,388 \\
Bartlett Küresellik Testi & df & 190 \\
& p &, 000 \\
\hline
\end{tabular}

Kaiser-Meyer-Olkin örneklem uygunluk katsayısı ,823 ve Bartlett Küresellik Testi $(\chi 2=3261,388 ; p=, 00)$ sonucunun ,01 düzeyinde anlamlı çıkması Tablo 4'te görüldüğü gibi verilerin faktör analizine uygun olduğunu ve verilerin çok değişkenli normal dağılıma sahip olduğunu göstermektedir. Açımlayıcı faktör analizinde ölçeğin çok faktörlü yapıda olması planlanmış ve bu durum varimax dik döndürme tekniği ile kanıtlanmıştır. Elde edilen sonuçlar Tablo 4'te verilmiştir.

Tablo 4.

Psikolojik Sözleşme Algısı Ölçeğinin Boyutlarının Özdeğerleri ve Açıkladıkları Varyans Yüzdeleri

\begin{tabular}{lcccccc}
\hline \multirow{2}{*}{ Faktör } & \multicolumn{3}{c}{ Başlangıç Özdeğerleri } & \multicolumn{3}{c}{ Açılanan Varyans } \\
& & $\begin{array}{c}\text { Varyans } \\
\%\end{array}$ & $\begin{array}{c}\text { Kümülatif } \\
\%\end{array}$ & Toplam & $\begin{array}{c}\text { Varyans } \\
\%\end{array}$ & $\begin{array}{c}\text { Kümülatif } \\
\%\end{array}$ \\
\hline 1 & 5,714 & 28,569 & 28,569 & 5,677 & 28,387 & 28,387 \\
2 & 2,595 & 12,974 & 41,542 & 2,613 & 13,064 & 41,452 \\
3 & 2,411 & 12,055 & 53,597 & 2,429 & 12,145 & 53,597 \\
\hline
\end{tabular}


Tablo 4'teki değerlere göre okul yöneticilerinin psikolojik sözleşme algısı ölçeğinin özdeğeri 1'den büyük üç boyuttan oluştuğu görülmektedir. Sosyal bilimlerde açıklanan varyansın \%40 ile \%60 arasında olması yeterli kabul edilmektedir (Çokluk, Şekercioğlu ve Büyüköztürk, 2010; Tavşancıl, 2005). Birinci boyutun (ilişkisel psikolojik sözleşme) toplam varyansın \%28,387'sini, ikinci boyutun (dengeli psikolojik sözleşme) toplam varyansin \%13,064'ünü ve üçüncü boyutun (işlemsel psikolojik sözleşme) toplam varyansın \%12,145' ini açıkladığı tespit edilmiştir.

Üç boyutun ölçekteki toplam varyansın \% 53,597'sini açılamakta olduğu görülmektedir. Buna göre üç faktörlü psikolojik sözleşme algısı ölçeğinin açıkladığı toplam varyansın $(\% 53,597)$ yeterli kabul edildiği söylenebilir. Faktör analizine ait özdeğer çizgi grafiği incelendiğinde ölçeğin üç boyutlu olduğu görülmektedir (Şekil 1).

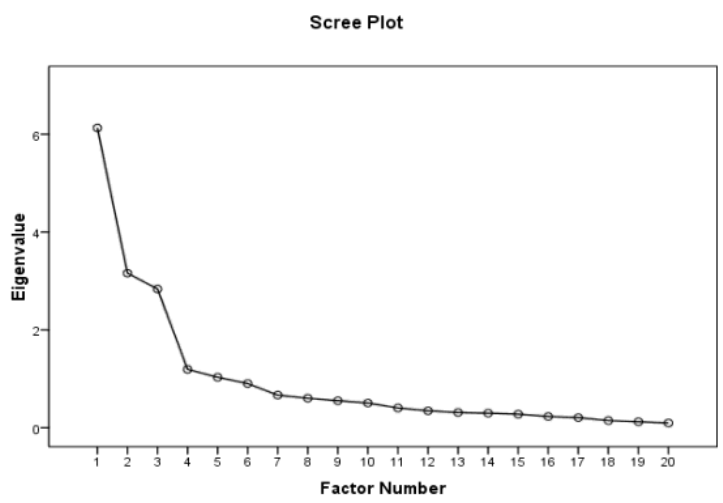

Şekil 1. Psikolojik Sözleşme Algısı Ölçeği Özdeğer Grafiği

Psikolojik sözleşme algısı ölçeğinin açımlayıcı faktör analizi sonuçları Tablo 5’te verilmişsir.

Tablo 5.

Psikolojik Sözleşme Algısı Ölçeğinin Açımlayıcı Faktör Analizi Sonuçları

\begin{tabular}{cccc}
\hline $\begin{array}{c}\text { Madde } \\
\text { No }\end{array}$ & Faktör 1 & Faktör 2 & Faktör 3 \\
\hline 9 &, 920 & & \\
12 &, 904 & & \\
10 &, 877 & & \\
11 &, 819 & & \\
8 &, 750 & & \\
13 &, 716 & & \\
16 &, 705 & & \\
15 &, 636 & & \\
14 &, 523 &, 952 & \\
17 &, 513 &, 806 &, 840 \\
18 & &, 671 &, 793 \\
19 & &, 537 &, 568 \\
20 & & &, 472 \\
22 & & & \\
21 & & & \\
6 & & & \\
7 & & & \\
2 & & & \\
5 & & & \\
3 & & & \\
\hline
\end{tabular}


Faktör yük değeri için 0,60 ve üstü yük değeri yüksek; $0,30-0,59$ aras1 yük değeri orta düzeyde büyüklükler olarak tanımlanabilir (Büyüköztürk, 2002, 2018). Tabachnick ve Fidell'e (2007) göre yük değeri minimum 0,32 olması gerekmektedir. Tablo 5'te 22 maddelik 3 faktör yapılı ölçek için maddelerin faktörlere dağılımı incelenmiştir. 20 maddenin faktör yük değerinin 0,45 'ten büyük olduğu görülmektedir. İşlemsel sözleşme boyutundaki M1 "Yasal düzenlemeler bana gelecekte bu okulda çalışacağıma dair bir güvence vermemektedir." ile M4 "Sadece işimin gereklerini yerine getiririm." maddeleri açımlayıcı faktör analizi sonucu ,32 minimum değeri karşılamadığından ölçek taslağından çıkarılmıştır. Psikolojik sözleşme algısı ölçeğine ilişkin veriler açımlayıcı faktör analizine tabi tutulmuş ve üç faktörlü bir yapı ortaya çıkmıştır.

\section{Doğrulayıcı faktör analizi}

Elde edilen bulgulardan ölçeğin üç faktörlü yapısının incelenmesi için doğrulayıcı faktör analizi yapılmıştır. Açımlayıcı faktör analizinden sonra doğrulayıcı faktör analizi (DFA) için 2018-2019 eğitim-öğretim yılında uygulama alanı dışında kalan farklı okullarda görev yapan okul yöneticilerine ölçek dağıtılmıştır. Geri dönüş sağlanan 252 ölçek ile doğrulayıcı faktör analizi yapılmıştır. 20 maddelik psikolojik sözleşme algısı ölçeğinin doğrulayıcı faktör analizinin 252 katılımc ile yapılmış olması örneklem büyüklüğünün yeterli olduğunu göstermektedir. Buna göre elde edilen bulgular Şekil 2 ve Tablo 6'da paylaşılmıştır.

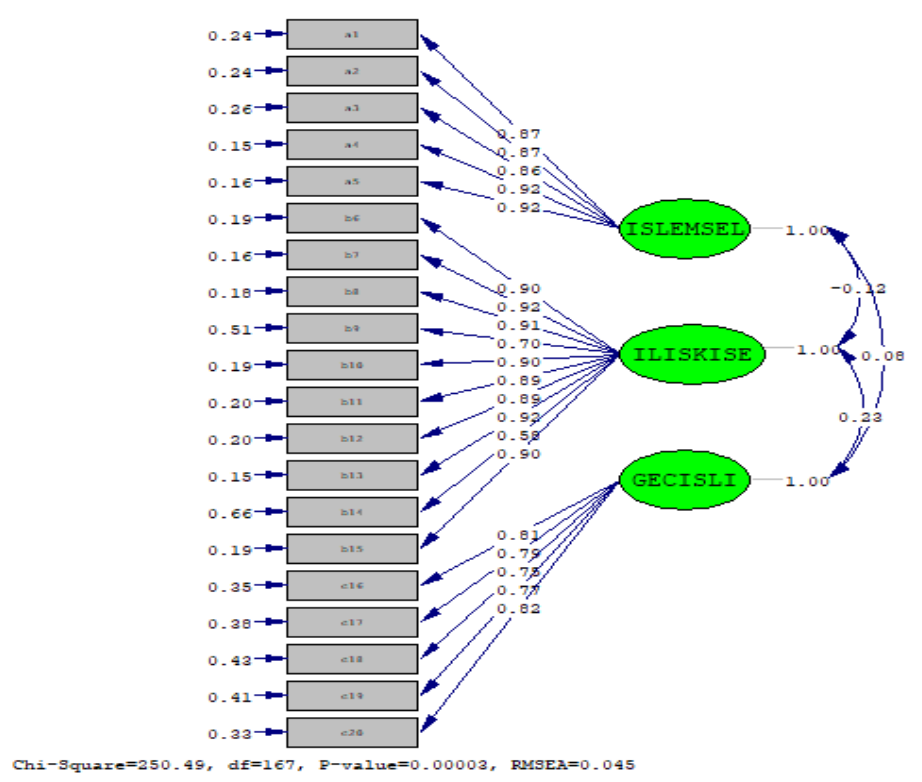

Şekil 2. Psikolojik Sözleşme Algısı Ölçeği Ölçme Modeli

Tablo 6.

Psikolojik Sözleşme Algısı Ölçeği Doğrulayıcı Faktör Analizi Sonuçları

\begin{tabular}{lllll}
\hline Faktör & Maddeler & $\mathrm{t}$ & $\lambda$ & $\mathrm{R}_{2}$ \\
\hline & 1 & 43,64 & 0,87 & 0,76 \\
İşlemsel & 2 & 40,33 & 0,87 & 0,76 \\
Sözleşme & 3 & 36,70 & 0,86 & 0,74 \\
& 4 & 55,36 & 0,92 & 0,85 \\
& 5 & 52,96 & 0,92 & 0,84 \\
\hline & 6 & 51,10 & 0,90 & 0,81 \\
İlişkisel & 7 & 58,43 & 0,92 & 0,84 \\
Sözleşme & 8 & 51,42 & 0,91 & 0,82 \\
& 9 & 19,35 & 0,70 & 0,49 \\
& 10 & 51,00 & 0,90 & 0,81 \\
& 11 & 47,82 & 0,89 & 0,80 \\
\hline
\end{tabular}




\begin{tabular}{|c|c|c|c|c|}
\hline & 12 & 50,01 & 0,89 & 0,80 \\
\hline & 13 & 58,71 & 0,92 & 0,85 \\
\hline & 14 & 13,49 & 0,58 & 0,34 \\
\hline & 15 & 49,26 & 0,90 & 0,81 \\
\hline \multirow{5}{*}{$\begin{array}{l}\text { Dengeli } \\
\text { Sözleşme }\end{array}$} & 16 & 27,22 & 0,81 & 0,65 \\
\hline & 17 & 25,57 & 0,79 & 0,62 \\
\hline & 18 & 23,15 & 0,75 & 0,57 \\
\hline & 19 & 24,09 & 0,77 & 0,59 \\
\hline & 20 & 29,50 & 0,82 & 0,67 \\
\hline \multicolumn{5}{|l|}{ Uyum Değeri } \\
\hline$x^{2}$ & $\mathrm{p}$ & RMSEA & CFI & AGFI \\
\hline 250,49 & 0,00 & 0,045 & 0,99 & 0,97 \\
\hline
\end{tabular}

Tablo 6'da görüldüğg̈ gibi modeldeki faktör yükleri Psikolojik Sözleşme Algısı Ölçeği'nin geneli için $(\lambda)$ 0,58 ile 0,92 arasında değişmekte olup, bu faktör yüklerinin açıkladıkları varyanslar $\left(\mathrm{R}_{2}\right)$ 0,34 ile 0,85 arasında değişmektedir. Psikolojik Sözleşme Algısı Ölçeği'nin işlemsel boyutu için faktör yükleri $(\lambda) 0,86$ ile 0,92 arasında değişirken, bu faktör yüklerinin açıkladıkları varyanslar 0,74 ile 0,85 arasında; ilişkisel boyutu için faktör yükleri $(\lambda)$ 0,58 ile 0,92 arasında değişirken faktör yüklerinin açıkladıkları varyanslar 0,34 ile 0,85 arasında ve dengeli boyutu için faktör yükleri $(\lambda) 0,75$ ile 0,82 arasında değişirken faktör yüklerinin açıkladıkları varyanslar 0,57 ile 0,67 arasında değişmektedir. Doğrulayıcı faktör analizi uyum indeksleri değer aralıkları (Çokluk ve diğerleri, 2010; Hooper, Coughlan ve Mullen, 2008; Raykov ve Marcoulides, 2006; Schumacker ve Lomax, 2016; Sümer, 2000; Tabachnick ve Fidell, 2007) ve psikolojik sözleşme algısı ölçeğinin doğrulayıcı faktör analizi sonucu elde edilen uyum indeksleri Tablo 7'de gösterilmektedir. Ki-kare $\left(\chi_{2}\right)$ iyilik uyumu değerinin $\chi_{2}^{2}=250,49$, sd=167 şeklinde olduğu $x_{2} / s d$ oranının 1,50 ile modelin mükemmel uyuma sahip olduğu ortaya çıkmıştır.

Tablo 7.

Psikolojik Sözleșme Algısı Ölçeği Doğrulayıcı Faktör Analizi Uyum İndeksleri

\begin{tabular}{lllll}
\hline İndeks & $\begin{array}{l}\text { Kabul edilebilir } \\
\text { değer aralı̆̆ } 1\end{array}$ & $\begin{array}{l}\text { Mükemmel değer } \\
\text { aralı̆̆ } 1\end{array}$ & Değer & Karar \\
\hline$x 2 / s d$ & $2,00 \leq \mathrm{x}^{2} / \mathrm{sd} \leq 5,00$ & $, 00 \leq \mathrm{x}^{2} / \mathrm{sd}<2,00$ & 1,50 & Mükemmel \\
CFI &, $95 \leq \mathrm{CFI} \leq, 97$ & $, 97 \leq \mathrm{CFI} \leq 1,00$ & 0,99 & Mükemmel \\
GFI &, $85 \leq \mathrm{GFI} \leq, 95$ & $, 95 \leq \mathrm{GFI} \leq 1,00$ & 0,98 & Mükemmel \\
AGFI &, $85 \leq \mathrm{AGFI} \leq, 95$ & $, 95 \leq \mathrm{AGFI} \leq 1,00$ & 0,97 & Mükemmel \\
NFI &, $90 \leq \mathrm{NFI} \leq, 95$ & $, 95 \leq \mathrm{NFI} \leq 1,00$ & 0,96 & Mükemmel \\
NNFI &, $90 \leq \mathrm{NNFI} \leq, 95$ & $, 95 \leq \mathrm{NNFI} \leq 1,00$ & 0,98 & Mükemmel \\
IFI &, $90 \leq \mathrm{IFI} \leq, 95$ & $, 95 \leq \mathrm{IFI} \leq 1,00$ & 0,99 & Mükemmel \\
RFI &, $90 \leq \mathrm{RFI} \leq, 95$ & $, 95 \leq \mathrm{RFI} \leq 1,00$ & 0,95 & Mükemmel \\
SRMR &, $05 \leq \mathrm{SRMR} \leq, 10$ &, $00 \leq \mathrm{SRMR}<, 05$ & 0,099 & Kabul edilebilir \\
RMSEA &, $05 \leq \mathrm{RMSEA} \leq, 08$ &, $00 \leq \mathrm{RMSEA}<, 05$ & 0,045 & Mükemmel \\
\hline
\end{tabular}

Analizler sonucunda modele ilişkin uyum iyiliği indekslerine (Şekil 2; Tablo 7) göre GFI (iyilik uyum indeksi), AGFI (düzeltilmiş iyilik uyum indeksi), CFI (karşılaştırmalı uyum indeksi), NFI (normlaştırılmış uyum indeksi), NNFI (normlaştırılmamış uyum indeksi), IFI (fazlalık uyum indeksi) ve RFI (göreli uyum indeksi) uyum indeksleri için ,95 ve üstü değerler mükemmel uyumu; ,90 ve üstü değerler kabul edilebilir uyumu göstermektedir (Sümer, 2000). Doğrulayıc1 faktör analizi sonucu araştırmada CFI ,99; GFI ,98; AGFI ,97; NFI ,96; NNFI ,98; IFI ,99; RFI ,95 olarak bulunmuştur. Sonuç olarak elde edilen bu uyum indeksleri modelin mükemmel uyuma sahip olduğunu ortaya koymuştur. Tablo 7'deki değerler incelendiğinde; RMSEA (Yaklaşık Hataların Ortalama Karekökü) değeri ,045 ile model mükemmel uyum aralığında bulunmuştur. SRMR (Standartlaştırılmış Ortalama Hataların Karekökü) değerinin ,05 ve daha küçük olması iyi 
uyuma ve ,10 değerinden küçük olması kabul edilebilir uyuma karşılık gelmektedir (Browne ve Cudeck, 1993, akt. İlhan ve Çetin, 2014; Schermelleh-Engel, Moosbrugger ve Müller, 2003: 52). $\mathrm{Bu}$ durumda araştırmanın SRMR değerinin ,099 ile kabul edilebilir uyum seviyesinde olduğu söylenebilir. Doğrulayıcı faktör analizi sonucu elde edilen uyum indeksleri ile Okul Yöneticilerinin Psikolojik Sözleşme Algısı Ölçeği'nin 3 faktör ve 20 maddeden oluştuğu doğrulanmıştır. Sonuç olarak Okul Yöneticilerinin Psikolojik Sözleşme Algısı Ölçeğinin 3 boyut ve 20 maddeden (işlemsel /1-2-3-4-5. maddeler; ilişkisel/6-7-8-9-10-11-12-13-14-15. maddeler; dengeli/ 15-16-17-18-19-20.maddeler) oluştuğu görülmektedir.

\section{Psikolojik Sözleşme Algısı Ölçeği’nin güvenirlik çalışması}

Ölçeğin güvenirliğine ilişkin olarak Millward ve Hopkins (1998) ve Demirkasımoğlu'nun (2012) çalışmalarının ve mevcut çalışmanın Cronbach Alpha değerleri Tablo 8'de verilmiştir.

Tablo 8.

Psikolojik Sözleşme Algısı Ölçeğinin Güvenirlik Katsayıları

\begin{tabular}{lcrcccrc}
\hline & Boyut & $\begin{array}{c}\text { Madde } \\
\text { Sayısı }\end{array}$ & $\begin{array}{c}\text { Millward ve } \\
\text { Hopkins } \\
(1998)\end{array}$ & $\begin{array}{c}\text { Madde } \\
\text { Sayısı }\end{array}$ & $\begin{array}{c}\text { Demirkasım } \\
\text { oğlu (2012) }\end{array}$ & $\begin{array}{r}\text { Madde } \\
\text { Sayıs1 }\end{array}$ & $\begin{array}{c}\text { Çalışmanın } \\
\text { Cronbach } \alpha\end{array}$ \\
\hline Psikolojik & İşlemsel & 10 &, 62 & 6 &, 74 & 5 &, 697 \\
Sözleşme & İlişkisel & 7 &, 65 & 7 &, 75 & 10 &, 848 \\
Algısı & Dengeli & - & - & 7 &, 85 & 5 &, 953 \\
Ölçeği & Genel & 17 & - & - & - & 20 &, 877 \\
\hline
\end{tabular}

Tablo 8 incelendiğinde Demirkasımoğlu'nun (2012) çalışmasında işlemsel sözleşme, ilişkisel sözleşme ölçeklerinin Cronbach's alpha katsayılarının sırasıyla ,74 ve ,75 olduğu ve dengeli sözleşme ölçeğine ilişkin Cronbach Alpha değerinin , 85 olduğu görülmektedir. Rousseau (2000) tarafından geliştirilen Psikolojik Sözleşme Envanteri'nin güvenirlik çalışmasında ölçeklerin her birisinin Cronbach's alpha katsayılarının ,70 ve üzerinde olduğu belirlenmiştir (akt. Demirkasımoğlu, 2012). Mimaroğlu'nun (2008) çalışmasında psikolojik sözleşme ölçeğinin Cronbach's alpha katsayı ,68 olarak bulunmuştur. Bu çalışmada ölçeğin güvenirliğine ilişkin olarak Cronbach Alpha değerleri işlemsel sözleşme boyutunda ,70; ilişkisel sözleşme boyutunda ,85; dengeli sözleşme boyutunda ,95 ve toplam psikolojik sözleşme ölçeğinde ,88 olarak hesaplanmıştır. Bu durumda ölçeğin güvenilir olduğu söylenebilir.

Okul yöneticilerinin psikolojik sözleşme algılarına ilişsin betimsel analiz

Okul yöneticilerinin psikolojik sözleşme algılarına ilişkin elde edilen verilerle hesaplanan aritmetik ortalama ve standart sapma değerleri Tablo 9'da verilmiştir.

Tablo 9.

Yöneticilerin Psikolojik Sözleşme Algılarına İlişkin Betimsel Analiz Sonuçları

\begin{tabular}{lllc}
\hline & Boyut & $\overline{\mathrm{x}}$ & Standart Sapma \\
\hline Psikolojik & İşlemsel Sözleşme & 3,21 &, 82575 \\
Sözleşme & İlişkisel Sözleşme & 3,99 &, 65494 \\
Algis1 & Dengeli Sözleşme & 3,58 &, 98283 \\
& Toplam & 3,69 &, 59195 \\
\hline
\end{tabular}

Psikolojik sözleşme boyutlarına bakıldığında okul yöneticilerinin görüşlerine göre ilişkisel sözleşme boyutu $(\overline{\mathrm{X}}=3,99)$ ve dengeli sözleşme boyutu $(\overline{\mathrm{X}}=3,58)$; toplam psikolojik sözleşme $(\overline{\mathrm{X}}=3,69)$ için ortalamaları "katıllyorum" düzeyinde olurken okul yöneticilerinin işlemsel sözleşme algısı ( $\overline{\mathrm{X}}=3,21)$ ise "kararsızım" düzeyindedir. Bu durumda okul yöneticilerinin psikolojik sözleşme algısı ile çalıştıkları okula aidiyet hissetme, sadakat ve bağlılık duygularını 
güçlendirmeye yönelik başarılı yöneticilere aynı okulda çalışmaya devam edebilmeleri için imkân verilmesi önemli olmaktadır.

$\mathrm{Bu}$ çalışmadaki okul yöneticilerinin ilişkisel sözleşme algılarının en yüksek; işlemsel sözleşme algılarının en düşük düzeyde olduğu bulgusu alanyazındaki çok sayıdaki çalışma ile benzerlik göstermektedir (Demirkasımoğlu, 2012; Dönmez, 2015; Envergil, 2018; Topcu, 2015). Dönmez (2015) tarafından yapılan çalışmada da öğretmenlerin genel psikolojik sözleşme ortalamasının, ilişkisel ve dengeli sözleşme alt boyutlarından daha düşük, işlemsel sözleşme alt boyutundan anlamlı derecede daha yüksek olduğu görülmüştür. Psikolojik sözleşme algılarının öğretmenler için orta düzeyde (Özdemir ve Demircioğlu, 2015; Öztürk, Eryeşil ve Damar, 2018) olduğu belirtilmiştir.

Shuping (2009) tarafindan bilgi işçileriyle yapılan araştırmada çalışanların en çok ilişkisel sözleşme ve en az işlemsel sözleşme düzeylerine sahip oldukları, eğitim ve gelişimin ilişkisel ve dengeli sözleşmelerin geliştirilmesinde en önemli insan kaynakları uygulaması olarak algılandığı; geçici ve işlemsel psikolojik sözleşme sahiplerinin tamamen ilişkisel ve dengeli çalışanların tersi olduğu; ilişkisel sözleşme algısına sahip çalı̧̧anlara tersine geçici çalışanlar üzerinde en yüksek etkiye sahip olan insan kaynakları uygulamasının ücret olduğu ve geçici çalışanların yalnızca kendi çıkarları için örgütte bulundukları ifade edilmektedir. Büyükyılmaz'ın (2013) çalışmasında Türkiye'de bulunan üniversitelerde görevli akademik personel tarafindan ekonomik faktörlerden çok duygusal faktörlerle ilgili algıların önemli olduğu; manevi unsurların yerine getirilmesinin önemli olduğu belirtilmektedir. Genel olarak, çalışanların ilişkisel sözleşme düzeylerinin işlemsel sözleşmeden yüksek çıktığ çalışmaların sağlık ve eğitim alanlarında yapıldığg görülmektedir. Bu durum akademisyenler, öğretmenler ve sağlık çalışanları gibi meslek gruplarının çalışma hayatında fedakârlık, özverili çalışma, örgütsel bağlılık kavramlarının ön planda olması ile açıklanabilir.

\section{Sonuç ve Öneriler}

Okul yöneticilerinin psikolojik sözleşme algılarını belirlemeye yönelik ölçek geliştirme çalışması yapılmıştır. AFA uygulaması sonucu elde edilen 20 maddelik ölçeğe DFA uygulaması farklı araştırma grubu üzerinde yapılmıştır. DFA sonucu uyum indeksleri CFI ,99; GFI ,98; AGFI ,97; NFI ,96; NNFI ,98; IFI ,99; RFI ,95 olarak bulunmuş ve elde edilen uyum indeksleri ile Okul Yöneticilerinin Psikolojik Sözleşme Algısı Ölçeği'nin 3 faktör ve 20 maddeden oluştuğu doğrulanmıştır. Sonuç olarak Okul Yöneticilerinin Psikolojik Sözleşme Algısı Ölçeğinin 3 boyut ve 20 maddeden oluştuğu görülmektedir. Güvenirliği belirlemek için Cronbach's alpha iç tutarlılık katsayısı hesaplanmıştır. Cronbach Alpha değerleri işlemsel sözleşme boyutunda ,70; ilişkisel sözleşme boyutunda ,85; dengeli sözleşme boyutunda ,95 ve toplam psikolojik sözleşme ölçeğinde , 88 olarak hesaplanmıştır. Bu doğrultuda ölçeğin güvenilir olduğu söylenebilir.

Okul yöneticilerinin psikolojik sözleşmeye ilişkin görüşlerinin betimsel analizi sonucu yöneticilerin ilişkisel sözleşme, dengeli sözleşme ve toplam psikolojik sözleşme algılarının katılıyorum düzeyinde ve işlemsel sözleşme algılarının ise "kararsızım" düzeyinde olduğu tespit edilmiştir. Psikolojik sözleşme düzeylerinde en yüksek ortalamaya sahip boyutun ilişkisel; en düşük ortalamaya sahip boyutun işlemsel sözleşme boyutu olduğu görülmektedir. Psikolojik sözleşmelerin işlemsel ve ilişkisel unsurlara ayrılabileceğini öne süren kavramsallaştırmalar bulunmaktadır (Robinson ve diğerleri, 1994; Rousseau, 1990; Turnley, Bolino, Lester ve Bloodgood, 2003). Alanyazında işlemsel ve ilişkisel psikolojik sözleşmelerin çift kutuplu olduğu görüşü de savunulmaktadır (Millward ve Hopkins, 1998; Özgen ve Özgen, 2010). Çalışanların görüşlerine göre sosyal takasa ve uzun süreli ilişkilerin ilişkisel sözleşme algılarının daha olumlu olduğu belirlenmiştir. Genel olarak işlemsel sözleşme algısının düşük olması olumlu değerlendirilirken ilişkisel sözleşme algısının yüksek olması beklenmektedir. İşlemsel ve ilişkisel sözleşme boyutları ile ilgili bu bulgular alanyazındaki çalışmaları destekler niteliktedir (Dikili, 2012; Dönmez, 2015; Topcu, 2015; Yılmaz, 2012). Bu anlamda Envergil'in (2018) çalışmasında ilişkisel sözleşmenin işlemsel sözleşmeye göre birey ve örgüt için daha olumlu sonuçlar ortaya koyduğu belirtilmektedir. 
Eğitim sistemindeki değişimlere bağlı olarak öğretmenlerin ve dolayısıyla yöneticilerin görev ve sorumluluklarının kapsamında artış görülmektedir. Tüm bu artan yükümlülükler okul yöneticilerinin karşılık beklentilerini doğurmaktadır. Bu beklentiler ekonomik unsurların yanı sıra sosyal unsurları da içermektedir. Okul yöneticileri için başarı, önemli oranda yönetici ile üst yönetim-örgüt arasındaki psikolojik sözleşme algısına bağlı olabilmektedir. Psikolojik sözleşme algısını arttırmak için üst yönetimin beklentilerini okul yöneticilerine net bir şekilde açıklaması ve ödüllendirme imkânlarının hangi kriterlere göre verildiğini adalet ve güvenilirlik algısını sağlamak için açık bir şekilde ifade etmesi yararlı olacaktır. Aynı zamanda yönetici seçim kriterlerinin ve atanan yöneticilerin hangi kriterler göz önünde bulundurularak atandığının açıkça ifade edilmesi yöneticilerle birlikte görev yapan öğretmenlerin ve diğer okul yöneticilerinin psikolojik sözleşme algısını etkilemektir.

Çalışma hayatı boyunca hem bireyin hem de örgütün karşılıklılık ilkesine göre beklentilerinin karşılanıp karşılanmaması psikolojik sözleşmenin etkileşim sürecinde farklılaşmasını ve döngüsel varlığını devam ettirmesini sağlamaktadır. Kautz ve Bjerknes'e (2015) göre psikolojik sözleşmeleri birkaç döngü boyunca kötü bir şekilde devam ettiği için bireyler çalışma hayatını sona erdirmektedir. Psikolojik sözleşmeler çalışanların tutum ve davranışlarını anlama ve tahmin etme girişiminde bulunmak için kullanılabilmektedir (McLean Parks, Kidder ve Gallagher, 1998). Çalışanların psikolojik sözleşme kavramı farklı yönleriyle ele alınmıştır: Örgüt ve çalışan ilişkisi (Rousseau, 1989, 2001; Robinson ve Rousseau, 1994; Rousseau ve McLean Parks, 1993; Shore ve Tetrick, 1994), insan kaynakları uygulamaları (Guest ve Conway, 2002), karşıllıklılık kavramı (Coyle-Shapiro ve Kessler, 2002), psikolojik sözleşme ile örgütsel vatandaşlık davranışları (Robinson ve Morrison, 1995), karşılıklılık normu (Tekleab ve Taylor, 2003), psikolojik sözleşme ihlalinin sonuçları (Robinson, 1996; Robinson ve Morrison, 1995; Turnley ve Feldman, 2000). Bu doğrultuda okul yöneticilerinin psikolojik sözleşme algısının arttırılmasının önemi ortaya çıkmaktadır.

Psikolojik sözleşme istihdam ilişkisini ve çalışan davranışlarını anlamak için önemli bir araç olarak görülmektedir (Conway ve Briner, 2002, 2009; Guest, 2004). Bu bağlamda okul yöneticilerinin psikolojik sözleşme algısının incelenmesi yönetici atama sürecini düzenlemeye, başarılı ve istekli öğretmenlerin yönetici olma yönelimlerini arttırmaya, öğretmenlerin ve çalışanların örgütsel davranışlarını olumlu yönde etkilemeye yönelik yöntemler geliştirilmesi için yararlı olacağı düşünülmektedir. Araştırma ile ilgili aşağıdaki öneriler sunulmuştur: (1) Üst yönetim okul yöneticileri ile etkili iletişimi sağlamak için yöntemler geliştirmelidir. (2) Okullar ziyaret edilerek, toplantı ve görüşmeler yapılarak üst yönetimle okul yöneticileri arasındaki beklentiler ve yükümlülükler açıç̧a belirlenmelidir. (3) Yöneticilerin psikolojik sözleşme algılarının farklı kavramlar ve teorilerle ilişkisi araştırılabilir.

\section{Etik Kurul Onay Bilgileri}

Çalışma Bolu Abant İzzet Baysal Üniversitesi Sosyal Bilimlerde İnsan Araştırmaları Etik Kurulu 26.03.2019 tarihli ve 2019/3 (protokol no. 2019/136) sayılı izni ile yapılmıştır.

\section{Kaynaklar}

Anderson, N. ve Schalk, R. (1998). The psychological contract in retrospect and prospect. Journal of Organizational Behavior: The International Journal of Industrial, Occupational and Organizational Psychology and Behavior, 19(1), 637-647.

Argyris, C. (1960). Understanding organizational behavior. Homewood, Dorsey Press.

Aselage, J. ve Eisenberger, R. (2003). Perceived organizational support and psychological contracts: A theoretical integration. Journal of Organizational Behavior: The International Journal of Industrial, Occupational and Organizational Psychology and Behavior, 24(5), 491-509.

Bilgin, L. (2007). Psikolojik sözleşmelerin oluşumu, gelişimi ve ihlalinde toplu ve bireysel sözleşmelerin rolü. Eskişehir Osmangazi Üniversitesi Sosyal Bilimler Dergisi, 8(1).

Büyüköztürk, Ş. (2002). Faktör analizi: Temel kavramlar ve ölçek geliştirmede kullanımı. Kuram ve Uygulamada Eğitim Yönetimi, 32(32), 470-483. 
Büyüköztürk, Ş. (2018). Sosyal bilimler için veri analizi el kitabı. Ankara: Pegem Akademi.

Büyükyılmaz, O. (2013). Akademik personel açısından psikolojik sözleşme ihlali ile işten ayrılma niyeti arasındaki ilişsilerin analizi. Yayınlanmamış Doktora Tezi, Bülent Ecevit Üniversitesi Sosyal Bilimler Enstitüsü, Zonguldak.

Conway, N. ve Briner, R. B. (2002). A daily diary study of affective responses to psychological contract breach and exceeded promises. Journal of Organizational Behavior, 23, 287302.

Conway, N. ve Briner, R. B. (2009). Fifty years of psychological contract research: What do we know and what are the main challenges. International Review of Industrial and Organizational Psychology, 24(71), 71-131.

Conway, N. ve Coyle-Shapiro, J. A. M. (2012). The reciprocal relationship between psychological contract fulfilment and employee performance and the moderating role of perceived organizational support and tenure. Journal of Occupational and Organizational Psychology, 85(2), 277-299.

Coyle-Shapiro, J. A. M. ve Kessler, I. (2002). Exploring reciprocity through the lens of the psychological contract: employee and employer perspectives. Journal of Work and Organizational Psychology, 11, 69-86.

Coyle-Shapiro, J. A-M. ve Parzefall, M. (2008). Psychological contracts. Cooper, Cary L. ve Barling, Julian (Yay. haz.). The SAGE Handbook of Organizational Behavior içinde (ss. 17-34). London, UK: SAGE Publications.

Cullinane, N. ve Dundon, T. (2006). The psychological contract: A critical review. International Journal of Management Reviews, 8(2), 113-129.

Çokluk, Ö., Şekercioğlu, G. ve Büyüköztürk, Ş. (2010). Sosyal bilimler için çok değişkenli istatistik: SPSS ve LISREL uygulamaları. Pegem Akademi.

Dabos, G. E. ve Rousseau, D. M. (2004). Mutuality and reciprocity in the psychological contracts of employees and employers. Journal of Applied Psychology, 89(1), 52-72.

De Vos, A., Buyens, D. ve Schalk, R. (2003). Psychological contract development during organizational socialization: Adaptation to reality and the role of reciprocity. Journal of Organizational Behavior: The International Journal of Industrial, Occupational and Organizational Psychology and Behavior, 24(5), 537-559.

Demirkasımoğlu, N. (2012). Кати ve özel ilköğretim okulu sinif öğretmenlerinin psikolojik sözleşme algilari ve iş çevresine uyum düzeyleri ile iliş̧kisi (Yayımlanmamış doktora tezi). Ankara Üniversitesi Eğitim Bilimleri Enstitüsü, Ankara.

Dikili, A. (2012). Psikolojik sözleşme ile iş tatmini ilişkisi: Bir örnek olay çalışması. (Yayımlanmamış doktora tezi). Sakarya Üniversitesi Sosyal Bilimler Enstitüsü, Sakarya.

Dönmez, N. (2015). Ortaokullarda görev yapan öğretmenlerin psikolojik sözleşme düzeyleri ile örgütsel bağlllıkları arasındaki ilişski (Yayımlanmamış yüksek lisans tezi). Uşak Üniversitesi Sosyal Bilimler Enstitüsü, Uşak.

Envergil, D. (2018). Sağglk çalişanlarinin psikolojik sözleşme algilarinin örgütsel güven, örgütsel özdeşleşme ve örgütsel vatandaşlik davranişi üzerindeki etkisi (Yayımlanmamış doktora tezi). Hacettepe Üniversitesi Sosyal Bilimler Enstitüsü, Ankara.

Erkorkmaz, Ü., Etikan, I., Demir, O., Özdamar, K. ve Sanisoğlu, S. Y. (2013). Doğrulayıcı faktör analizi ve uyum indeksleri. Türkiye Klinikleri Journal of Medical Sciences, 33(1), 210223.

Guest, D. E. (2004). The psychology of the employment relationship: An analysis based on the psychological contract. Applied Psychology, 53(4), 541-555.

Guest, D. E. ve Conway, N. (2002). Communicating the psychological contract: An employer perspective. Human Resource Management Journal, 12(2), 22-38.

Herriot, P. ve Pemberton, C. (1997). Facilitating new deals. Human Resource Management Journal, 7(1), 45-56.

Hooper, D., Coughlan, J. ve Mullen, M. R. (2008). Structural equation modelling: Guidelines for determining model fit. Electronic Journal of Business Research Methods, 6(1), 53-60. 
İlhan, M. ve Çetin, B. (2014). LISREL ve AMOS programları kullanılarak gerçekleştirilen yapısal eşitlik modeli (YEM) analizlerine ilişkin sonuçların karşılaştııılması. Eğitimde ve Psikolojide Ölçme ve Değerlendirme Dergisi, 5(2), 26-42.

Kaldırımc1, N. (1987). Motivasyon için anahtar bir kavram: Psikolojik sözleşme. Erciyes Üniversitesi Sosyal Bilimler Enstitüsü Dergisi, 1.

Kautz, K. ve Bjerknes, G. (2015). Tales of it consultants: Understanding psychological contract maintenance and employment termination. Australasian Journal of Information Systems, 19, 71-95.

Kotter, J. P. (1973). The psychological contract: Managing the joining-up process. California Management Review, 15, 91-99.

Lawshe, C. H. (1975). A quantitative approach to content validity. Personnel Psychology, 28(4), 563-575.

Levinson, H., Price, C. R., Munden, K. J., Mandl, H. J. ve Solley, C. M. (1962). Men, management, and mental health. Cambridge, MA, US: Harvard University Press.

MacNeil, I. (1985). Relational contracts: What we do and do not know. Wisconsin Law Review, 483-525.

Maguire, H. (2002). Psychological contracts: are they still relevant? Career Development International, 7(3), 167-180.

McLean Parks, J., Kidder, D. L. ve Gallagher, D. G. (1998). Fitting square pegs into round holes: Mapping the domain of contingent work arrangements onto the psychological contract. Journal of Organizational Behavior, 19, 697-730.

Miles, J. A. (2012). Management and organization theory: A Jossey-Bass Reader. John Wiley \& Sons.

Millward, L. J. ve Hopkins, L. J. (1998). Psychological contracts, and job commitment. Journal of Applied Psychology, 28(16), 1530-1556.

Mimaroğlu, H. (2008). Psikolojik sözleşmenin personelin tutum ve davranişlarina etkileri: Tibbi satış temsilcileri üzerinde bir araştırma (Yayımlanmamış doktora tezi). Çukurova Üniversitesi Sosyal Bilimler Enstitüsü, Adana.

Özdemir, M. ve Demircioğlu, E. (2015). Devlet liselerinde üretim karşıtı iş davranışları ve psikolojik sözleşme ilişkisi. Çukurova Üniversitesi Eğitim Fakültesi Dergisi, 44(1), 4159.

Özgen, M. H. ve Özgen, H. (2010). Psikolojik sözleşme ve boyutlarının iş tatmini, örgütsel bağlılık ve işten ayrılma niyetine etkileri; Tıbbi satış temsilcileri üzerine bir araştırma. Ç.Ü. Sosyal Bilimler Enstitüsü Dergisi, 19(1), 1-19.

Öztürk, M., Eryeşil, K. ve Damar, A. (2018). Psikolojik sözleşme algısının örgütsel vatandaşlık davranışı üzerindeki etkisinde örgütsel güvenin aracılık rolü. Electronic Turkish Studies, 13(26), 985-1000.

Patrick, H. (2008). Psychological contract and employment relationship. The Icfai University Journal of Organizational Behavior, VII (4), 7-24.

Raykov, T. ve Marcoulides, G. A. (2006). On multilevel model reliability estimation from the perspective of structural equation modeling. Structural Equation Modeling, 13(1), 130141.

Robinson, S. L. (1996). Trust and breach of the psychological contract. Administrative Science Quarterly, 41, 574-599.

Robinson, S. L., Kraatz, M. S. ve Rousseau, D. M. (1994). Changing obligations and the psychological contract: A longitudinal study. Academy of Management Journal, 37, 137152.

Robinson, S. L. ve Morrison, E. W. (1995). Psychological contracts and OCB: The effect of unfulfilled obligations on civic virtue behavior. Journal of Organizational Behavior, 16, 289-298.

Robinson, S. L. ve Rousseau, D. M. (1994). Violating the psychological contract: Not the exception but the norm. Journal of Organizational Behavior, 15(3), 245-259. 
Rousseau, D. M. (1989). Psychological and implied contracts in organizations. Employee Responsibilities and Rights Journal, 2(2), 121-139.

Rousseau, D. M. (1990). New hire perceptions of their own and their employer's obligations: A study of psychological contracts. Journal of Organizational Behavior, 11, 389-400.

Rousseau, D. M. (1995). Psychological contracts in organizations: Understanding written and unwritten agreements. Thousand Oaks, CA: Sage.

Rousseau, D. M. (2000). Psychological contract inventory technical report. Pittsburgh: Carnegie Mellon University, 1-52.

Rousseau, D. M. (2001). Schema, promise and mutuality: the building blocks of the psychological contract. Journal of Occupational and Organizational Psychology,74, 511-541.

Rousseau, D. M. ve McLean Parks, I. M. (1993). The contracts of individuals and organizations. Research in Organizational Behavior, 15, 41-43.

Rousseau, D. M. ve Wade-Benzoni, K. A. (1994). Linking strategy and human resource practices: How employee and customer contracts are created. Human Resource Management, 33(3), 463-489.

Schermelleh-Engel, K., Moosbrugger, H. ve Müller, H. (2003). Evaluating the fit of structural equation models: Tests of significance and descriptive goodness-of-fit measures. Methods of Psychological Research Online, 8(2), 23-74.

Schumacker, R. E. ve Lomax, R. G. (2016). A beginner's guide to structural equation modeling. NY: Routledge.

Shore, L. M. ve Tetrick, L. E. (1994). The psychological contract as an explanatory framework in the employment relationship. C. L. Cooper ve D. M. Rousseau (Yay. haz.). Trends in Organizational Behavior, içinde (say1. 1, ss. 91-109). New York: Wiley.

Shuping, J.G. (2009). The impact of human resource practices on the psychological contract: A quantitative study (Yüksek lisans tezi). University of Pretoria, Pretoria.

Sümer, N. (2000). Yapısal eşitlik modelleri: Temel kavramlar ve örnek uygulamalar. Türk Psikoloji Yazıları, 3(6), 49-74.

Tabachnick, B. G. ve Fidell, L. S. (2007). Using multivariate statistics. Allyn \& Bacon/Pearson Education.

Tavşancıl, E. (2005). Tutumların ölçülmesi SPSS veri analizi. Ankara: Nobel Yayınları.

Tekleab, A. ve Taylor, S. (2003). Aren't there two parties in the employment relationship? Antecedents and consequences of organization-employee agreement on contract obligations and violations. Journal of Organizational Behavior, 24, 585-608.

Tezcan, C. (2008). Yapısal eşitlik modelleri (Yayımlanmamış yüksek lisans tezi). Hacettepe Üniversitesi Fen Bilimleri Enstitüsü, Ankara.

Topcu, M. K. (2015). Çalışanların kişilik özelliklerinin örgütsel özdeşleşme ve işten ayrılma niyeti üzerine etkisinde psikolojik sözleşme algısının rolü (Yayımlanmamış doktora tezi). Kara Harp Okulu Savunma Bilimleri Enstitüsü, Ankara.

Turnley, W. H., Bolino, M. C., Lester, S. W. ve Bloodgood, J. M. (2003). The impact of psychological contract fulfillment on the performance of in-role and organizational citizenship behaviors. Journal of Management, 29(2), 187-206.

Turnley, W. H. ve Feldman, D. C. (2000). Re-examining the effects of psychological contract violations: unmet expectations and job dissatisfaction as mediators. Journal of Organizational Behavior, 21, 25-42.

Yılmaz, A. (2012). Psikolojik sözleşme ve örgütsel güven arasındaki ilişkinin analizi: teorik ve uygulamalı bir çalışma (Yayımlanmamış yükssek lisans tezi). Selçuk Üniversitesi Sosyal Bilimler Enstitüsü, Konya.

\section{Extended Abstract}

\section{Introduction}

Psychological contract emphasizes to unwritten expectations among employees and organizations. Contracts that serve to achieve the achievement of organizational goals, to bring 
together individuals and organizations and to regulate their behaviors are a necessary feature of organizations (Robinson, Krattz \& Rousseau, 1994). Transactional and relational are key components of the psychological contract (Aselage \& Eisenberger, 2003; De Vos, Buyens \& Schalk, 2003; Macneil, 1985; Millward \& Hopkins, 1998; Rousseau, 1995, 2000; Rousseau \& McLean Parks, 1993). In employment, arrangements can be transaction, relational or a hybrid form as in the case of high performance work teams. Relational contract are long-term or openended employment arrangements based upon mutual trust and loyalty. Balanced contract are dynamic and open-ended employment arrangements conditioned on economic success of firm and worker opportunities to develop career advantages. Transactional contract are employment arrangements with a short-term or limited duration, primarily focused upon economic exchange. Transactional refers to short-term arrangements that are highly monetary or economic in focus. In contrast, relational refers to open-ended arrangements that comprise socioemotional as well as economic terms (Rousseau, 2000).

\section{Purpose}

In this study, it is aimed to develop a psychological contract perception scale to examine school administrators' perceptions of psycological contracts. Thus, findings are expected to be obtained in order to determine the psychological contract perceptions of school administrators who have important expectations and obligations in educational organizations.

\section{Method}

In this study, the psychological contract perception of school administrators was analyzed in three dimensions as operational, relational and balanced contract. The psychological contract scale that developed by Millward and Hopkins (1998) and by adapted in Turkish by Mimaroğlu (2008) consists of 'transactional' and relational 'relational' dimensions. Psychological Contract Inventory that developed by Rousseau (2000) and adapted in Turkish by Demirkasımoğlu (2012) has balanced contract dimension. The related literature was searched and new items were added to the scale. According to expert opinions, Lawshe's Content Validity Ratio of each item was calculated. Content Validity Ratio of the items was found to be 0.62 and above by calculation method is given by Lawshe (1975). A scale of 22 items was obtained. As a result of the exploratory factor analysis, two items were excluded from the scale. The total variance of the psychological contract perception scale consisting of three dimensions was found to be $53,60 \%$. The 20-item CFA was applied to different research groups. According to the results of confirmatory factor analysis, chi-square $(\chi 2)$ goodness-fit value was $\chi^{2}=250.49$, sd $=167$; The

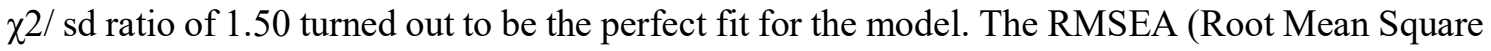
Error of Approximation) value was 0.045 and the model was perfectly fit and the SRMR (Standardized Root Mean Square Residual) value was 0.099 and it was acceptable. The SRMR value of 0.05 and less corresponds to good fit, and less than 0.10 corresponds to acceptable fit (Browne \& Cudeck, 1993; From. İlhan \& Çetin, 2014; Schermelleh-Engel, Moosbrugger \& Müller, 2003, p. 52). CFI (Comparative Fit Index) was found to be 0.99; GFI (Goodness of Fit Index) 0.98; AGFI (Adjusted Goodness of Fit Index) 0.97; NFI (Normed Fit Index) 0.96; NNFI (Non-normed Fit Index) 0.98; IFI (Incremental Fit Index) 0.99; The RFI (Relative Fit Index) was found to be 0.95 .

\section{Results}

The results of the confirmatory factor analysis showed that the Psychological Contract Perception Scale had excellent fit values. The psychological contract perception scale consists of transactional, relational and balanced contract dimensions. The scale has 5-point Likert scale form that Strongly disagree $(1 / 1,00-1,79)$, Disagree $(2 / 1,80-2,59)$, Neither agree nor disagree $(3 / 2,60$ $3,39)$, Agree $(4 / 3,40-4,19)$, Strongly agree $(5 / 4,20-5,00)$. Data were obtained from three different groups for exploratory factor analysis, confirmatory factor analysis, and final application. The arithmetic mean and standard deviation values of the scores obtained from the psychological contract scale were examined. Within the scope of scale development to determine 
the views of school administrators about psychological contract perception, the Psychological Contract Perception Scale with 20 items and 3 dimensions (transactional /5 items, relational /10 items, balanced/5 items) was obtained. Cronbach's alpha coefficient was calculated to determine reliability. The Cronbach Alpha values of this study were 0.70 for transactional contract; 0.85 for relational contract; 0.95 for balanced contract and 0.88 for total psychological contract scale.

It was aimed to determine the opinions of school administrators about psychological contract perception by applying descriptive analysis. In the final application, the scale was applied to 249 school administrators in primary, secondary and high school in Bolu, and it was found that school administrators' views about psychological contract perception. It was determined that the school administrators' perceptions of relational contract, balanced contract and total psychological contract were at the level of agree, and the perceptions of transactional contract were at the level of 'neither agree nor disagree'. Accordingly, it is important to increase the perception of the school administrators' psychological contracts.

\begin{tabular}{|c|c|c|c|c|c|c|}
\hline Oku & PSİKOLOJIKK SÖZLEŞME ALGISI ÖLÇEĞİ & 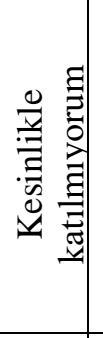 & 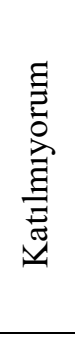 & 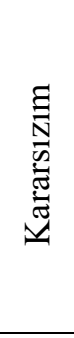 & 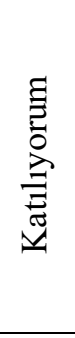 & שֶ, \\
\hline 1 & $\begin{array}{l}\text { Bu okuldaki görevim, açıkça tanımlanmış belli yetki ve } \\
\text { sorumluluklarla sınırlandırılmıştır. }\end{array}$ & $($ ) & $($ ) & $($ ) & $($ ) & ( ) \\
\hline 2 & $\begin{array}{l}\text { Üst yönetim benim, rutin görevleri yerine getirmemi } \\
\text { beklemektedir. }\end{array}$ & $(\mathbf{)}$ & $($ ) & $(\mathrm{l})$ & $($ ( ) & ( ) \\
\hline 3 & Net olarak belirlenmiş iş saatleri içinde çalışmayı tercih ederim. & ( ) & $(\mathrm{)}$ & ( ) & ( ) & ( ) \\
\hline 4 & Fazla çalışma için maddi kazanç ve ek ödeme almayı beklerim. & () & $($ ( ) & () & $($ ( ) & () \\
\hline 5 & $\begin{array}{l}\text { Sadece belirlediğim kısa dönemli hedeflere ulaşmak için } \\
\text { çalısıırım. }\end{array}$ & ( ) & ( ) & ( ) & ( ) & ( ) \\
\hline 6 & Maddi karşıllı̆̆ olmayan görevleri de isteyerek yaparım. & $(\mathrm{c})$ & $($ ( ) & $(\mathrm{c})$ & $($ ) & ( ) \\
\hline 7 & Çalıştığım kurumda her konuda fazlasıyla sorumluluk üstlenirim. & $(\mathrm{c})$ & $($ ) & $(\mathrm{c})$ & $($ ) & ( ) \\
\hline 8 & Bu kurumda kendimi takımın önemli bir parçası gibi hissederim. & ( ) & ( ) & ( ) & ( ) & ( ) \\
\hline 9 & Bu okulda uzun süre çalışmak isterim. & ( ) & ( ) & ( ) & $($ ) & ( ) \\
\hline 10 & $\begin{array}{l}\text { Hedeflere ulaşmak için gösterdiğim çabanın karşılığını almayı } \\
\text { beklerim. }\end{array}$ & ( ) & ( ) & ( ) & ( ) & ( ) \\
\hline 11 & Yönetici olarak görevime devam etmek isterim. & () & $($ ( ) & () & $($ ( ) & () \\
\hline 12 & Üst yönetim karar alırken, kişisel görüşlerimi dikkate alır. & ( ) & ( ) & ( ) & ( ) & ( ) \\
\hline 13 & Üst yönetim, yaşadığım sorunlara karşı duyarlı davranır. & () & () & () & () & () \\
\hline 14 & Üst yönetim, bir çalışan olarak kişisel mutluluğumu önemser. & () & () & () & $($ ) & $($ ) \\
\hline 15 & $\begin{array}{l}\text { Üst yönetim, bu okuldan uzun vadede memnuniyetimi sağlamak } \\
\text { için üzerine düşeni yapar. }\end{array}$ & ( ) & ( ) & ( ) & ( ) & ( ) \\
\hline 16 & $\begin{array}{l}\text { Üst yönetim mümkün olan en üst düzeyde performansı } \\
\text { gösterebilmem için beni destekler. }\end{array}$ & ( ) & $($ ( ) & $($ ( ) & $($ ( ) & $($ ) \\
\hline 17 & $\begin{array}{l}\text { Üst yönetim, eğitimde giderek yükselen standartları yerine } \\
\text { getirebilmem için bana yardımcı olur. }\end{array}$ & ( ) & $($ ） & $($ ( ) & $($ ( ) & $($ ) \\
\hline 18 & $\begin{array}{l}\text { Üst yönetim değişen şartlara uyum sağlayabilmem için gerekli } \\
\text { olanakları sağlar. }\end{array}$ & ( ) & $($ ） & $($ ( ) & ( ) & ( ) \\
\hline 19 & $\begin{array}{l}\text { Çalıştığım kurum, mesleki gelişimimi sağlayacak eğitim ve } \\
\text { yetişme olanakları sunar. }\end{array}$ & ( ) & ( ) & ( ) & ( ) & ( ) \\
\hline 20 & Çalıştığım kurum, görevde yükselmem için fırsatlar sunar. & $($ ) & $($ ) & () & ( ) & $($ ) \\
\hline
\end{tabular}

